Techniques \& Culture

\title{
Technologie comparée des Wayana et Aluku de Guyane française
}

\section{Robert Cresswell}

\section{(2) OpenEdition \\ 1 Journals}

Édition électronique

URL : https://journals.openedition.org/tc/937

DOI : $10.4000 /$ tc. 937

ISSN : 1952-420X

Éditeur

Éditions de l'EHESS

\section{Édition imprimée}

Date de publication : 1 février 1986

ISSN : 0248-6016

\section{Référence électronique}

Robert Cresswell, «Technologie comparée des Wayana et Aluku de Guyane française », Techniques \& Culture [En ligne], 6 | 1986, mis en ligne le 24 janvier 2006, consulté le 29 septembre 2022. URL : http:// journals.openedition.org/tc/937 ; DOI : https://doi.org/10.4000/tc.937

Ce document a été généré automatiquement le 29 septembre 2022.

Tous droits réservés 


\section{Technologie comparée des Wayana et Aluku de Guyane française}

Robert Cresswell 